\title{
A Comparative Study Establishing the Importance of Physiotherapeutic Principles and Body Composition Analysis in Promoting Independent and Healthy living Among Randomized Geriatric Population of Indore District.
}

\author{
Rohit Subhedar \\ Multi Specialty Department of Physiotherapy, Bombay Hospital- Indore-India
}

\section{Introduction}

This research proposal for PhD studies in Physiotherapy aims towards healthy, happy and independent geriatric life style. In the past few years the interest in body composition, nutritional status and physical independence in elderly people has markedly increased because of the increasing number of elderly people in the general population and its implication for geriatric health care ${ }^{1-2}$. Advancing age results in body composition changes such as decrease in fat free mass ${ }^{3-4}$, and increase in fat mass ${ }^{4-6}$. Also, the amount of minerals in the fat free mass changes ${ }^{7}$; as does the ratio of total body water in form of intercellular to intracellular water ${ }^{8-12}$. Geriatric ageing is usually characterized by loss of skeletal muscle mass and function, termed as sarcopenia ${ }^{13}$. Both physical inactivity and inadequate nutritional intake are the main contributing factors to sarcopenia and reduction in fat free mass ${ }^{14-15}$. These changes have been associated with dramatic functional decline, physical frailty, falls in elderly and a bad quality of geriatric life ${ }^{16-18}$. Until now very few studies have investigated both the effects of (a) nutritional supplementation and (b) exercises on nutritional status, body composition and muscular function among geriatric population ${ }^{19-21}$. Few studies showed that resistance training improved muscle size but nutritional supplements had no effects on any primary outcome of energy intake, body composition or thigh muscle area ${ }^{20}$. De Jong et al. observed a slight improvement of lean body mass and energy intake with exercises. ${ }^{21}$ No significant studies were available on the effects of functional independence, quality of geriatric life with changing body composition parameters and effects of Physiotherapy in form of combination of electro and exercise therapy as a part of regular geriatric care in improving quality of geriatric life. This void in clinical research among Indian population that too among those geriatric individuals who were associated with our Physiotherapy Department, prompted me to conduct a comprehensive research on body composition parameters of unaware elderly and aware elderly population. These elderly were evaluated twice (Pre and Post Physiotherapy interventions) at a gap of six months to prove the benefits of Physiotherapy in improving quality of geriatric life. It is seen that lean body mass peaks in the third to fourth decade of life, followed by a steady decline with advancing age ${ }^{22-23}$ This decline in muscle mass is associated with weakness, disability and morbidity ${ }^{24-26}$. In contrast, body weight increases until 60 years of age; thereafter $>=60 \%$ of the population experiences a decrease in weight $\mathrm{t}^{27-31}$. Obesity is a major public health problem in the general population, although weight loss in the elderly has a more detrimental effect on health or physical function than on equivalent amount of weight gain ${ }^{32-35}$. It is also seen that weight gain, characterized by a greater percentage of fat than lean tissue, has been reported in men and women $<60$ years of age ${ }^{36-41}$. Many studies also showed body composition changes during the ageing process resulting in a decrease of Total Body Water, Bone mass, Body cell mass and Fat free mass ${ }^{2}$. These changes in body composition among elderly, increases the risk of developing a wide range of chronic disorders including hypercholesterolemia, atherosclerosis, hyperinsulinemia, insulin resistance and non-insulin dependent Diabetes and hypertension. ${ }^{42}$ Aging-associated changes of body composition have been well described in cross-sectional studies ${ }^{43-45}$ and are known to have a relevant impact on health. Aging-related loss of lean body mass is among the causes of poor balance and falls in elderly ${ }^{46}$ while abdominal fat accumulation is associated to the metabolic syndrome among geriatric population. ${ }^{47}$

Besides muscle mass loss, muscle quality is also decreased with aging. ${ }^{48}$ Increased intramuscular fat and collagen tissue in elderly muscles ${ }^{49-50}$ are associated with decreased strength ${ }^{51}$ and poor lower extremity 
performance.$^{52}$ Similarly, total body potassium (TBK), an index of the metabolically active cellular mass, ${ }^{53}$ was also found to correlate with lower limb strength in over 80 -year-old nursing-home residents. ${ }^{54}$

It is known that intracellular potassium concentration remains constant with aging whereas its content in fat-free mass decreases progressively from age 30 to 80 , suggesting that metabolically active cellular mass is reduced in the muscle of elderly people. ${ }^{54}$

Because of the important implications of body composition in the development of disease and physical dependency, there is a large interest in understanding the progression of body composition modification to prevent or, at least, attenuate it. In this regard, several studies have shown the beneficial effect of physical activity. Strength training prevents muscle wasting ${ }^{55-56}$ and preserves physical independence, while aerobic exercise reduces the risk of cardiovascular events. ${ }^{57-58}$

Less clear are the findings about the role of leisure-time physical activity in attenuating the development of sarcopenia and the increase of body fat, while some studies showed no effect on fat-free mass loss, ${ }^{59}$ nor relationship with appendicular skeletal muscle mass ${ }^{60}$ other findings ${ }^{61-62}$ suggest that leisure-time physical activity could delay fat-free mass loss and fat mass (FM) gain. In addition, all of these studies, except one, ${ }^{60}$ provide cross-sectional data, while it would be important to define the role of physical activity in longitudinal settings.

Our Hypothesis (1) States that physical activity in form of any spontaneous activities such as walking or FBER (Full Body Exercise Regime), hobbies and recreational sports, 4F Diet Technique, and Physiotherapy interventions might be effective, In mitigating the loss of lean body mass, preserving muscle cellular mass, delaying body fat accumulation and aging in randomized geriatric population of Indore District. (2) States that difference in segmental body fat distribution shall be an indicator for musculoskeletal disorders.

Aim and Objectives of this study is (1) To investigate body composition changes in a population of elderly subjects in apparent good health and active (2) To evaluate the impact of regular Physiotherapy in form of physical exercises (FBER) program as derived by us, $4 \mathrm{~F}$ Diet Principle as derived by us, and electrotherapeutic interventions for reducing effects of aging and age-related body composition changes among randomized Geriatric Population of Indore - District.

\section{Literature Review}

1. M. Bonnefoy1, 2,3,4, C. Cornu5, S. Normand2, F. Boutitie6, F. Bugnard5,A. Rahmani4, J. R. Lacour4 and M. Laville2,3 studied The effects of exercise and protein-energy supplements on body composition and muscle function in frail elderly individuals: a long-term controlled randomized study showed that A long-term combined intervention is feasible in frail elderly individuals with a good rate of compliance. Nutritional supplements and exercise may improve muscle function. Despite no significant results on FFM, due to the limited number of volunteers, combined intervention should be suggested to counteract muscle weakness in the frail elderly.

2. DK Dey1, 2,3*, 1 Bosaeus 2, L Lissner 3,4, B Steen 1 Body composition estimated by bioelectrical impedance in the Swedish elderly. Development of population-based prediction equation and reference values of fat-free mass and body fat for 70- and 75-y olds and the results of the study showed the FFMBIA correlated well with FFM4C ( $\left.\mathrm{r}^{1} / 40.95, \mathrm{SEE}^{1} / 42.64 \mathrm{~kg}\right)$. The FFMBIA $(\mathrm{kg})$ in 70 -y-old males and females were 58.575 .4 and 43.474.4, and for 75-y-old males and females were 56.174.7 and 42.574, respectively. The body fat in $\mathrm{kg}$ (FM) among 70-y-old males and females were 25.278.1 and 25.778.4, and for 75-y-old males and females were 21.777.1 and 22.8p7.2, respectively. The percent body fat (BF\%) among 70-y-old males and females were 29.575.8 and 36.376.4, and for 75-y-old males and females were 27.376 and 34.176.1, respectively. Conclusion of study was the FFM, FM and BF\% from this study might be used as reference values for Swedish elderly aged 70 and $75 \mathrm{y}$.

3. Barbara Sternfeld1, Long Ngo2, William A. Satariano2, and Ira B.Tager studied the Association of Body Composition with Physical Performance and Self-reported Functional Limitation in Elderly Men and Women and the findings suggest that fat mass negatively impacts some domains of physical performance and 
overall functioning, while lean mass is less significant in absolute terms but is important relative to amount of body fat.

4. Comasia Addolorata Raguso Ursula Kyle Michel Picard Kossovsky Catherine Roynette Ariane Paoloni-Giacobino Didier Hans Laurence Genton Claude Pichard done a 3-year longitudinal study on body composition changes in the elderly: Role of physical exercise, and concluded Mild but significant decline in muscle mass and its TBK content, and body fat accumulation were observed over a 3-year period in healthy elderly subject: leisure-time physical activity does not seem to prevent them. However, a higher level of physical activity is associated with higher muscle mass and TBK content, and less total and truncal fat.

5. Virginia A Hughes, Walter R Frontera, Ronenn Roubenoff, William J Evans, and Maria A Fiatarone Singh studied longitudinal changes in body composition in older men and women: role of body weight change and physical activity. On average, FM increased; however, the increase in women was attenuated with advancing age. The decrease in FFM over the follow-up period was small and masked the wide interindividual variation that was dependent on the magnitude of weight change. The contribution of weight stability, modest weight gains, or lifestyle changes that include regular resistance exercise in attenuating lean-tissue loss with age should be explored.

\section{Study Methodology:}

Subjects: The total study shall include on an average 300/500 subjects.

The subjects shall be divided in to three Major Groups.

Group A: Population between the age group 41 to 50 years

Total Number of Subjects $=100$

Males $=50$ Females $=50$

Group B: Population between the age group 51 to 60 years

Total Number of Subjects $=100$

Males $=50$ Females $=50$

Group C: Population between the age group 61 to 75 years

Total Number of Subjects $=100$

Males $=50$ Females $=50$

Method of Analytical Research and Grouping:

Each Group Individuals will be initially evaluated for their Body Composition parameter analysis. Based upon the results a proper Physiotherapy consultation will be provided and appropriate Exercise prescription shall be given to the elderly. The technique derived for efficacy and prescription shall be termed as FBER program having 18 types of safe total body slow gradual and safe works out of Elderly. Prescription of electrotherapy Modalities will also be given to those having pain and discomfort as and when required. All this individuals from each group shall be reassessed after a period of 6 Months, through Body composition analysis with Tanita BC 418 Body Composition Analyzer.

Inter AND Intra Group statistical assessment shall be done to establish significant results.

Group A, B, C = Pre Assessment Group Group A1, B2, C3 = Post Treatment Group

Group A

Group A1

Group B

Group B2

Group C

Group C3

Method of Analysis - Bioelectrical Impedance method of Analysis

Technical Specification: Materials

1. Tanita Bc 418 Body Composition Analyzer

Principle: Bioelectrical impedance

The key to the TANITA MEDICAL range is accuracy and simplicity. The analyzers are fast, easy to use and can be linked to data capture and trend analysis software allowing less time -consuming paperwork and more consultation time. All Tanita body composition analyzers meet the strict MDD and NAWI European regulation relation relating to the weighing mechanism.

Segmental reading separates into fat $\%$ mass, fat free mass and predicted muscles mass for: 
1. Right Arm

2. Right Leg

3. Left Arm

4. Left Leg

5. Trunk

Tanita BC- 418 Body Composition Analyzer

Tanita B.C.A- Gives Print Out For:

1. Weight

2. BMI

3. BMR

4. Fat $\%$

5. Fat Mass

6. Fat Free Mass

7. Total Body Water

8. Desirable Body Fat Ranges

9. Segmental Body Fat Information

Materials used:

1.FAT CHART

2. BMI CHART

3. WEIGHT CHART

4. DIGITAL WEIGHING MACHINE

5. HEIGHT CHART

6. TANITA BODY COMPOSITION ANALYSER

7. FITNESS SOFTWEAR and FITNESS PROFILE

Time to Evaluate: 5 min per patient

Outcome Measures

Height

Weight

Body fat $\%$

Fat mass

Fat free mass/ Lean Body Mass

Basal Metabolic Rate

Right and left leg fat mass

Right and left arm fat mass

Trunk fat mass

\section{Variables-}

Independent Variables-

Room ergonomics

Patient psychology and emotional status

Religious

Economical status

Body composition analysis

\section{Dependent Variables-}

Weight

Height

Fat mass

Fat free mass

BMR 
Segmental fat mass

Nutrition and Diet

Data analysis- Data analysis between-

$\mathrm{G}_{\mathrm{A}}$ vs. $\mathrm{G}_{\mathrm{B}}$ vs $\mathrm{G}_{\mathrm{A} 1}$ vs. $\mathrm{G}_{\mathrm{B} 1}$

$\mathrm{G}_{\mathrm{A}}$ vs. $\mathrm{G}_{\mathrm{C}}$ vs $\mathrm{G}_{\mathrm{A} 1}$ vs. $\mathrm{G}_{\mathrm{Cl}}$

$\mathrm{G}_{\mathrm{B}}$ vs. $\mathrm{G}_{\mathrm{C}}$ vs $\mathrm{GB} 1$ vs. $\mathrm{G}_{\mathrm{C} 1}$

\section{Statement of Problem}

A comparative study establishing the Importance of Physiotherapeutic Principles and Body Composition Analysis in Promoting Independent and healthy living Among Randomized Geriatric Population of Indore District. This research proposal for my PhD studies in Physiotherapy aims towards healthy, happy and independent geriatric life style.

\section{References:}

[1]. Munro HN, Nutrition and ageing. Br Med Bull 1981; 37:83-8

[2]. Steen B. Nutrition and ageing. Nutr rev 1988; 46:45-51.

[3]. Forbes GB. The adult decline in lean body mass. Hum Biol 1976; 48:161-73.

[4]. Novak LP. Ageing, total body potassium, fat free mass and cell mass in males and females between ages 18 and 85 years. J Gerontol 1972; 27:438-43.

[5]. Noppa H, Andersson M, Bengtsson C, Bruce A, Isaksson B. Body composition in middle-aged women with special reference to the correlation between body fat mass and anthropometric data. Am J Clin Nutr 1979; 32:1388-95.

[6]. Durnin JVGA, Womersley J. Body fat assessed from total body density and its rstimation from skinfold thickness: measurements on 481 men and women aged from 16 to 72 years. Br J Nutr 1974; 32:77-97.

[7]. Mazess RB. On aging bone loss. Clin Orthop Res 1982; 165:239-52.

[8]. Forbes GB. Human body composition. New York: Springer Verlage, 1988.

[9]. Friss-Hansen B. Hydrometry of growth and ageing. In: Brozek J, ed. Human body composition. Oxford: Peragamon Press, 1965:191-209.

[10]. Borkan GA, Norris AH. Fat redistribution and the changing body dimensions of the adult male. Hum Biol 1977; 49:495-514.

[11]. Steen B, Isaksson B, Svanborg A. Body composition at 70 and 75 years of age; a longitudinal population study. J Clin Exp Gerontol 1979; 1:185-200.

[12]. Steen B. Body composition and ageing. Nutr Rev 1988; 46:40-6.

[13]. Gallagher D, Ruts E, Visser M, Heshka S, Baumgartner RN, Wang J, Pierson RN, Pi-Sunyer FX \& Heymsfield SB (2000) Weight stability masks sarcopenia in elderly men and women. American Journal of Physiology and Endocrinology Metabolism 279, E366-E375.

[14]. Campbell WW, Crim MC, Young VR \& Evans WJ (1994) Increased energy requirements and changes in body composition with resistance training in older adults. American Journal of Clinical Nutrition 60, 167-175.

[15]. Millward DJ, Fereday A, Gibson N \& Pacy PJ (1997) Aging, protein requirements, and protein turnover. American Journal of Clinical Nutrition 66, 774-786.

[16]. Chumlea W, Guo S, Glaser R \& Vellas B (1997) Sarcopenia, function and health. Nutrition and Health 1, 7-12.

[17]. Evans W (1997) Functional and metabolic consequences of sarcopenia. Journal of Nutrition 127, 998S-1003S.

[18]. Payette H, Hanusaik N, Bourier V, Morais JA \& Gray-Donald K (1998) Muscle strength and functional mobility in relation to lean body mass in free living frail elderly women. European Journal of Clinical Nutrition 52, 45-53.

[19]. Meredith CN, Frontera WR, O’Reilly KP \& Evans WJ (1992) Body composition in elderly men: effect of dietary modification during strength training. Journal of the American Geriatrics Society 40, 155-162.

[20]. Fiatarone MA, O’Neill EF, Doyle Ryan N, Clements KM, Solares GR, Lipsitz LA \& Evans WJ (1994) Exercise training and nutritional supplementation for physical frailty in very elderlypeople. New England Journal of Medicine $330,1769-1775$.

[21]. De Jong N, Chin A, Paw MJM, De Groot L, de Graaf C, Kok FJ \& Van Staveren WA (2000) Dietary supplements and physical exercise affecting bone and body composition in frail elderly persons. American Journal of Public Health 90, 947-954.

[22]. Allen T, Andersen EC, Langham WH. Total body potassium and gross body composition in relation to age. J Gerontol 1960;15:348-57.

[23]. Pierson RN, Lin DHY, Phillips RA. Total body potassium in health: effects of age, sex, height, and fat. Am J Physiol 1974;226:206-12. 
[24]. Baumgartner RN, Koehler KM, Gallagher D, et al. Epidemiology of sarcopenia among the elderly in New Mexico. Am J Epidemiol 1998; 147:755-63.

[25]. Frontera WR, Hughes VA, Lutz KJ, Evans WJ. A cross-sectional study of muscle strength and mass in 45- to 78-yrold men and women. J Appl Physiol 1991;71:644-50.

[26]. Hughes VA, Frontera WR, Wood M, et al. Longitudinal muscle strength changes in the elderly: influence of health, physical activity and body composition. J Gerontol A Biol Sci Med Sci 2001;56: B209-17.

[27]. Borkan GA, Norris AH. Fat redistribution and the changing body dimensions of the adult male. Hum Biol 1977;49:495-514. Downloaded from ajcn.nutrition.org by guest on May 30, 2013

[28]. Chumlea WC, Garry PJ, Hunt WC, Rhyne RL. Distributions of serial changes in stature and weight in a healthy elderly population. Hum Biol 1988;60:917-25.

[29]. Shimokata H, Andres R, Coon PJ, Elahi D, Muller DC, Tobin JD. Studies in the distribution of body fat. II. Longitudinal effects of change in weight. Int J Obes 1989;13:455-64.

[30]. Williamson DF. Descriptive epidemiology of body weight and weight change in US adults. Ann Intern Med 1993;119:646-9.

[31]. Rissanen AM, Heliovaara M, Aromaa A. Overweight and weight changes in 17000 adult Finns. Int J Obes 1988;12:391-401.

[32]. Manson JE, Willett WC, Stampfer MJ, et al. Body weight and mortality among women. N Engl J Med 1995;333:667-85.

[33]. Harris TB, Savage PJ, Tell GS, Haan M, Kumanyika S, Lynch JC. Carrying the burden of cardiovascular risk in old age: associations of weight and weight change with prevalent cardiovascular disease, risk factors, and health status in the cardiovascular health study. Am J Clin Nutr 1997;66:837-44.

[34]. Launer LJ, Harris T, Rumpel C, Madans J. Body mass index, weight changes and risk of mobility disability in middle-aged and older women. The epidemioogic follow-up of NHANES I. JAMA 1994; 271:1093-8.

[35]. Willett WC, Manson JE, Stampfer MJ, et al. Weight, weight changes and coronary heart disease in women. JAMA 1995;273:461-5.

[36]. Guo SS, Zeller C, Chumlea WC, Siervogel RM. Aging, body composition, and lifestyle: the Fels Longitudinal Study. Am J Clin Nutr 1999;70:405-11.

[37]. Marti B, Howald H. Long-term effects of physical training on aerobic capacity: controlled study of former elite athletes. J Appl Physiol 1990;69:1451-9.

[38]. Plowman SA, Drinkwater BL, Horvath SM. Age and aerobic power in women: a longitudinal study. J Gerontol 1979;34:512-20.

[39]. Sowers MF, Crutchfield M, Jannausch ML, Russell-Aulet M. Longitudinal changes in body composition in women approaching the midlife. Ann Hum Biol 1996;23:253-65.

[40]. Jackson AS, Wier LT, Ayers GW, Beard EF, Stuteville JE, Blair SN. Changes in aerobic power of women, ages 2064 yr. Med Sci Sports Exerc 1996;28:884-91.

[41]. Siervogel RM,Wisemandle W, Maynard LM, et al. Serial changes in body composition throughout adulthood and their relationships to changes in lipid and lipoprotein levels. The FELS Longitudinal Study. Arterioscler Thromb Vasc Biol 1998;18:1759-64.

[42]. Baumgartner RN, Heymsfield SB \& Roche AF (1995): Human body composition and the epidemiology of chronic disease. Obes. Rex. 3,73-95.

[43]. Kyle UG, Genton L, Hans D, et al. Total body mass, fat mass, fat-free mass, and skeletal muscle in older people: cross-sectional differences in 60-year-old persons. J Am Geriatr Soc. 2001;49(12):1633-1640

[44]. .Hansen RD, Raja C, Aslani A, Smith RC, Allen BJ. Determination of skeletal muscle and fat-free mass by nuclear and dual-energy X-ray absorptiometry methods in men and women aged 51-84 y (1-3). Am J Clin Nutr. 1999;70(2):228-233

[45]. Kyle UG, Genton L, Slosman DO, Pichard C. Fat-free and fat mass percentiles in 5225 healthy subjects aged 15 to 98 years.Nutrition. 2001;17(7-8):534-541

[46]. Janssen I, Heymsfield SB, Ross R. Low relative skeletal muscle mass (sarcopenia) in older persons is associated with functional impairment and physical disability. J Am Geriatr Soc. 2002;50(5):889-896

[47]. Van Pelt RE, Evans EM, Schechtman KB, Ehsani AA, Kohrt WM. Contributions of total and regional fat mass to risk for cardiovascular disease in older women. Am J Physiol Endocrinol Metab. 2002;282(5):E1023-E1028

[48]. Vandervoort AA. Aging of the human neuromuscular system. Muscle Nerve. 2002;25(1):17-25

[49]. Kent-Braun JA, Ng AV, Young K. Skeletal muscle contractile and noncontractile components in young and older women and men. J Appl Physiol. 2000;88(2):662-668

[50]. Overend TJ, Cunningham DA, Paterson DH, Lefcoe MS. Thigh composition in young and elderly men determined by computed tomography. Clin Physiol. 1992;12(6):629-640 
[51]. Goodpaster BH, Carlson CL, Visser M, et al. Attenuation of skeletal muscle and strength in the elderly: the health ABC study.J Appl Physiol. 2001;90(6):2157-2165

[52]. Visser M, Kritchevsky SB, Goodpaster BH, et al. Leg muscle mass and composition in relation to lower extremity performance in men and women aged 70 to 79 : the health, aging and body composition study. J Am Geriatr Soc.2002;50(5):897-904

[53]. Cohn SH, Vaswani AN, Yasumura S, Yuen K, Ellis KJ. Assessment of cellular mass and lean body mass by noninvasive nuclear techniques. J Lab Clin Med. 1985;105(3):305-311

[54]. Fiatarone MA, O'Neill EF, Ryan ND, et al. Exercise training and nutritional supplementation for physical frailty in very elderly people. N Engl J Med. 1994;330(25):1769-1775

[55]. Ades PA, Ballor DL, Ashikaga T, Utton JL, Nair KS. Weight training improves walking endurance in healthy elderly persons.Ann Intern Med. 1996;124(6):568-572

[56]. Irwin ML, Yasui Y, Ulrich CM, et al. Effect of exercise on total and intra-abdominal body fat in postmenopausal women: a randomized controlled trial. JAMA. 2003;289(3):323-330

[57]. Visser M, Launer LJ, Deurenberg P, Deeg DJ. Total and sports activity in older men and women: relation with body fat distribution. Am J Epidemiol. 1997;145(8):752-761

[58]. Hughes VA, Frontera WR, Roubenoff R, Evans WJ, Singh MA. Longitudinal changes in body composition in older men and women: role of body weight change and physical activity. Am J Clin Nutr. 2002;76(2):473-481

[59]. Starling RD, Ades PA, Poehlman ET. Physical activity, protein intake, and appendicular skeletal muscle mass in older men.Am J Clin Nutr. 1999;70(1):91-96

[60]. Baumgartner RN, Waters DL, Gallagher D, Morley JE, Garry PJ. Predictors of skeletal muscle mass in elderly men and women.Mech Ageing Dev. 1999;107(2):123-136

[61]. Dittmar M, Reber H, Hofmann G. Age-related decline in body cell mass in elderly men and women, determined by a noninvasive nuclear technique: effects of physical activity and dietary potassium intake. Am $\mathrm{J}$ Hum Biol. 2001;13(2):204-211

[62]. Kyle UG, Morabia A, Schutz Y, Pichard C. Sedentarism affects body fat mass index and fat-free mass index in adults aged 18 to 98 years. Nutrition. 2004;20(3):255-260 